Research Article

\title{
Study of profile of poisoning cases reported to district hospital, Chamarajanagar, Karnataka, India
}

\author{
${ }^{1}$ Department of Pharmacology, \\ ${ }^{2}$ Department of Forensic \\ Medicine and Toxicology, \\ Chamarajanagar Institute of \\ Medical Sciences, \\ Chamarajanagar, Karnataka, \\ India
}

Received: 28 June 2016 Accepted: 02 July 2016

\author{
*Correspondence to: \\ Dr. Yadukul S., \\ Email: dr.koooool@gmail.com
}

Copyright: (C) the author(s), publisher and licensee Medip Academy. This is an openaccess article distributed under the terms of the Creative Commons Attribution NonCommercial License, which permits unrestricted noncommercial use, distribution, and reproduction in any medium, provided the original work is properly cited.

\author{
Srinivasa K. ${ }^{1}$, Yadukul S. ${ }^{2}$, Megha Madyastha ${ }^{1}$
}

\begin{abstract}
Background: Poisoning is a major public health problem worldwide, with thousands of deaths occurring every year, mainly in the developing countries. India, holding $70 \%$ of agricultural land, accounts for one third of pesticide poisoning cases in the third world, the farm workers being the worst affected. Most of the poisonings occur due to deliberate self-ingestion of the poison. Organo-phosphorus (OP) compounds occupy the greatest burden of poisoning related morbidity and mortality. The present study was aimed to know the profile of various poisoning cases admitted to emergency department in district hospital, Chamarajanagar, Karnataka, India. The main objectives of this study were to determine the profile of poisoning cases reported to district hospital, Chamarajanagar and to assess their pattern and outcome.

Methods: A record based retrospective study for the year 2012 i.e. from $1^{\text {st }}$ January 2012 to $31^{\text {st }}$ December 2012 was conducted in district hospital, Chamarajanagar, Karnataka, India and the data regarding age, gender, residence, time elapsed after intake, type of poison, manner and route of poisoning, duration of hospitalization and outcome were collected in a prestructured proforma. The data was analyzed using standard statistical methods.

Results: In present study, rural hindu males were among the highest reported cases, with maximum number of cases reported during the month of March and during the 12:01 to 18:00 hours of the day. Irritant poisons accounts to the highest incidence $(68 \%)$ among poisoning in present study. Pesticides, organophosphorus compound in particular form the major type of poisons among irritants followed by snake bite, rat poison and honey bee bite (sting).

Conclusions: This study highlights the profile of poisoning cases admitted to the Chamarajanagar District, Karnataka, India which clearly indicates the high risk population involved and the common poisons encountered in these region.
\end{abstract}

Keywords: Poisoning, Pesticide, Organophosphorus, Chamarajanagar

\section{INTRODUCTION}

Poison is a substance that causes damage or injury to the body and endangers one's life due to its exposure by means of ingestion, inhalation or contact. ${ }^{1}$ Poisoning is a major public health problem worldwide, with thousands of deaths occurring every year, mainly in the developing countries. In the last few decades, owing to tremendous advances in the fields of agriculture, medical pharmacology and industrial technologies, there is a remarkable change in the profile of acute poisoning, where new poisonous substances have come to the forefront. In the developed world, household chemical agents and prescribed drugs have been the most common poisoning agents, whereas in the developing countries, agro-chemicals, in spite of their invaluable contribution in increasing the food production and pest control, are the most common offenders. ${ }^{2-5}$ Acute poisoning due to accidental and suicidal exposure causes significant mortality and morbidity throughout the world. According to World Health Organization (WHO), globally more than three million of acute poisoning cases with 2, 20,000 deaths occur annually. ${ }^{6}$ It has been estimated that, in India five to six persons per lakh of population die due to acute poisoning every year. ${ }^{7}$

Rapid industrialization, introduction of newer range of drugs for treatment and massive use of pesticides in agriculture has increased the incidence of poisoning. In advanced countries, it has been observed that poisoning deaths are mainly due to cleansing agents, detergents, paracetamol, carbon monoxide and other cosmetic 
products8. In India, as agriculture is the main occupation, insecticides and other agrochemical fertilizers are used to a greater extent and the poisoning with such products are more common. ${ }^{9}$

Knowledge of general pattern of poisoning in a particular region will help in early diagnosis and treatment of cases, thus decreasing the rate of mortality and morbidity. Information available in our locality with regard to acute poisoning is limited. Hence this present study was carried out with the objective to find out the pattern of poisoning cases in district hospital, Chamarajanagar, Karnataka, India.

\section{METHODS}

The present retrospective study was conducted in the casualty department of district hospital, Chamarajanagar attached to Chamarajanagar institute of medical sciences, Chamarajanagar, Karnataka, India for a period of 1year i.e., from $1^{\text {st }}$ January 2012 to 31 st December 2012. Ethical clearance had been taken from the institutional ethical committee prior to taking up the study. All the poisoning cases documented in the casualty department during the study period were included in the study. A detailed information regarding the age, sex, time of consumption of poison, type of poison, mode of transport to the hospital, reason for poisoning, amount of poison taken, route of entry into the body, time interval between the consumption and hospitalization, outcome and other parameters were noted down in detail in the proforma prepared prior to the study. Statistical analysis was carried out using latest statistical software.

\section{RESULTS}

Total number of medico-legal cases reported to casualty department, district hospital, Chamarajanagar, Karnataka, India during the study period was 2522. Out of the 2522 cases, 272 cases were due to poisoning, which accounts to $10.8 \%$. Among the 272 cases studied, $63.2 \%$ were males $(\mathrm{n}=172)$ and the age group between 19 years to 30 years constituted the major contributors $(48.1 \%)$ for poisoning cases (Table 1). Majority of the poisoning cases belonged to hindu religion $(96.3 \%)$ followed by muslims $(2.9 \%)$ and $75.7 \%(n=206)$ of the cases were reported from rural region (Table 2). Among the monthly distribution of cases
(Table 3), highest number of cases were reported during the month of March (12.1\%), closely followed by the month of June $(11 \%) .37 .1 \%(n=101)$ of cases occurred during the time gap between 12:01 hrs to 18:00 hrs (Table 4) closely followed by 18:01 hrs to 00:00 hrs (33.1\%). Out of the 272 cases studied, 174 cases $(64 \%)$ were reported to the hospital within $2 \mathrm{hrs}$ of the incident and 78 cases $(28.7 \%)$ were reported between 2-6 hrs (Table 5).

Table 1: Age and sex wise distribution of cases.

\begin{tabular}{|c|c|c|c|c|c|}
\hline \multicolumn{2}{|c|}{$\begin{array}{l}\text { Age group (years) } \\
\text { and sex }\end{array}$} & \multicolumn{2}{|c|}{$\begin{array}{l}\text { Number of } \\
\text { cases }\end{array}$} & \multicolumn{2}{|c|}{ Percentage } \\
\hline \multirow{2}{*}{$0-5$} & Male (M) & 3 & \multirow[b]{2}{*}{5} & $1.1 \%$ & \multirow{2}{*}{$1.8 \%$} \\
\hline & Female (F) & 2 & & $0.7 \%$ & \\
\hline \multirow{2}{*}{$6-18$} & M & 14 & \multirow{2}{*}{34} & $5.1 \%$ & \multirow{2}{*}{$12.5 \%$} \\
\hline & $\mathrm{F}$ & 20 & & $7.3 \%$ & \\
\hline \multirow{2}{*}{$19-30$} & M & 82 & \multirow{2}{*}{131} & $30.1 \%$ & \multirow{2}{*}{$48.1 \%$} \\
\hline & $\mathrm{F}$ & 49 & & $18 \%$ & \\
\hline \multirow{2}{*}{$31-50$} & M & 50 & \multirow{2}{*}{73} & $18.4 \%$ & \multirow{2}{*}{$26.8 \%$} \\
\hline & $\mathrm{F}$ & 23 & & $8.4 \%$ & \\
\hline \multirow{2}{*}{$>51$} & M & 20 & \multirow{2}{*}{26} & $7.3 \%$ & \multirow{2}{*}{$9.5 \%$} \\
\hline & $\mathrm{F}$ & 6 & & $2.2 \%$ & \\
\hline \multirow{2}{*}{$\begin{array}{l}\text { Don't } \\
\text { know }\end{array}$} & $\mathrm{M}$ & 3 & \multirow{2}{*}{3} & $1.1 \%$ & \multirow{2}{*}{$1.1 \%$} \\
\hline & $\mathrm{F}$ & 0 & & $0 \%$ & \\
\hline \multirow{2}{*}{\multicolumn{2}{|c|}{ Grand total }} & 172 & \multirow{2}{*}{272} & $63.2 \%$ & \multirow{2}{*}{$100 \%$} \\
\hline & & 100 & & $36.8 \%$ & \\
\hline
\end{tabular}

Table 2: Region and religion wise distribution of cases.

\begin{tabular}{|c|c|c|c|c|c|}
\hline \multicolumn{2}{|l|}{ Religion } & \multicolumn{2}{|c|}{ Number } & \multicolumn{2}{|c|}{$\begin{array}{l}\text { Percentage } \\
(\%)\end{array}$} \\
\hline \multirow{2}{*}{ Hindu } & Urban (U) & \multirow{2}{*}{262} & 61 & \multirow{2}{*}{96.3} & 22.4 \\
\hline & Rural (R) & & 201 & & 73.9 \\
\hline \multirow{2}{*}{ Muslim } & $\mathrm{U}$ & \multirow{2}{*}{8} & 3 & \multirow{2}{*}{2.9} & 1.1 \\
\hline & $\mathrm{R}$ & & 5 & & 1.8 \\
\hline \multirow{2}{*}{ Christian } & $\mathrm{U}$ & \multirow{2}{*}{1} & 0 & \multirow{2}{*}{0.4} & 0 \\
\hline & $\mathrm{R}$ & & 1 & & 0.4 \\
\hline \multirow{2}{*}{ Others } & $\mathrm{U}$ & \multirow{2}{*}{1} & 1 & \multirow{2}{*}{0.4} & 0.4 \\
\hline & $\mathrm{R}$ & & 0 & & 0 \\
\hline \multirow{2}{*}{\multicolumn{2}{|c|}{ Grand total }} & \multirow{2}{*}{272} & 206 & \multirow{2}{*}{100} & 75.7 \\
\hline & & & 66 & & 24.3 \\
\hline
\end{tabular}

Table 3: Month wise distribution of cases.

\begin{tabular}{|lllllllllllll|}
\hline Month & Jan & Feb & Mar & Apr & May & Jun & Jul & Aug & Sep & Oct & Nov & Dec \\
\hline Number & 26 & 27 & 33 & 18 & 20 & 30 & 22 & 29 & 19 & 19 & 10 & 19 \\
\hline Percent & $9.5 \%$ & $9.9 \%$ & $12.1 \%$ & $6.6 \%$ & $7.3 \%$ & $11 \%$ & $8 \%$ & $10.7 \%$ & $7 \%$ & $7 \%$ & $3.7 \%$ & $7 \%$ \\
\hline
\end{tabular}

Among the route of entry of poison (Table 6) into the human body, oral route constituted the highest number accounting to $73.5 \%(\mathrm{n}=200)$ among the cases studied.
Irritant poisons $(68 \%)$ were the most common type of poisons (Table 7) encountered in our study, with organophosphorus compounds $(25.7 \%)$ being the commonest 
sub-type among irritant poisons. The intention of poisoning (Table 8) was suicidal in $65.4 \%(n=178)$ of cases followed by accidental poisoning seen in $32.7 \%$ $(n=89)$ of cases studied. Among the cases who attempted suicidal poisoning, $92.1 \%(n=164)$ dint reveal the exact reason but only $5.1 \%(\mathrm{n}=9)$ of cases revealed that family problem (Table 9) was the reason they took poison. Among the persons accompanying the patient (Table 10) to the hospital, parents $(16.5 \%)$ formed the majority closely followed by siblings $(14.7 \%)$.

Table 4: Time of incident of poisoning cases.

\begin{tabular}{|lll|}
\hline Time of incident & $\begin{array}{l}\text { Total number } \\
\text { of cases }\end{array}$ & Percentage \\
\hline 00:01 to 06:00 hours & 20 & $7.4 \%$ \\
\hline 06:00 to 12:00 hours & 57 & $21 \%$ \\
\hline 12:01 to 18:00 hours & 101 & $37.1 \%$ \\
\hline 18:01 to 00:00 hours & 90 & $33.1 \%$ \\
\hline Don't know & 4 & $1.5 \%$ \\
\hline
\end{tabular}

Table 5: Time interval between incident and hospitalization.

\begin{tabular}{|lll|}
\hline Time interval & $\begin{array}{l}\text { Total number of } \\
\text { cases }\end{array}$ & Percentage \\
\hline$<2$ hours & 174 & $64.0 \%$ \\
\hline $2-6$ hours & 78 & $28.7 \%$ \\
\hline $6-24$ hours & 15 & $5.5 \%$ \\
\hline$>24$ hours & 5 & $1.8 \%$ \\
\hline
\end{tabular}

Table 6: Route of entry of poison into the body.

\begin{tabular}{|lll|}
\hline Route of entry & Total no. of cases & Percentage \\
\hline Oral & 200 & $73.5 \%$ \\
\hline Dermal & 1 & $0.4 \%$ \\
\hline Inhalation & 0 & $0 \%$ \\
\hline Intravenous & 0 & $0 \%$ \\
\hline Others & 71 & $26.1 \%$ \\
\hline
\end{tabular}

Table 7: Type and sub-types of the poisons studied.

\begin{tabular}{|c|c|c|c|c|c|}
\hline Type of poison & Poison Sub-type & Cases & & Percen & \\
\hline \multirow{3}{*}{ Corrosives } & Acids & \multirow{3}{*}{2} & 2 & \multirow{3}{*}{$0.7 \%$} & $0.7 \%$ \\
\hline & Alkali & & 0 & & $0 \%$ \\
\hline & Metallic salts & & 0 & & $0 \%$ \\
\hline \multirow{8}{*}{ Irritants } & OP poison & \multirow{8}{*}{185} & 70 & \multirow{8}{*}{$68 \%$} & $25.7 \%$ \\
\hline & Phosphides (rat poison) & & 29 & & $10.7 \%$ \\
\hline & Snake bite & & 42 & & $15.4 \%$ \\
\hline & Scorpion bite (sting) & & 6 & & $2.2 \%$ \\
\hline & Honey bee (sting) & & 26 & & $9.6 \%$ \\
\hline & Paint & & 1 & & $0.3 \%$ \\
\hline & Bangle & & 3 & & $1.1 \%$ \\
\hline & Others & & 8 & & $2.9 \%$ \\
\hline \multirow{6}{*}{ Systemic poison } & Alcohol & \multirow{6}{*}{43} & 6 & \multirow{6}{*}{$15.8 \%$} & $2.2 \%$ \\
\hline & Anti-depressants & & 5 & & $1.8 \%$ \\
\hline & Anti-psychotics & & 1 & & $0.3 \%$ \\
\hline & Analgesics & & 3 & & $1.1 \%$ \\
\hline & Paracetamol & & 10 & & $3.7 \%$ \\
\hline & Others & & 18 & & $6.6 \%$ \\
\hline Miscellaneous & Food poisoning & \multicolumn{2}{|l|}{2} & \multicolumn{2}{|l|}{$0.7 \%$} \\
\hline Unknown & - & \multicolumn{2}{|l|}{40} & \multicolumn{2}{|l|}{$14.7 \%$} \\
\hline
\end{tabular}

Table 8: Alleged manner of poisoning among the cases studied.

\begin{tabular}{|lll|}
\hline $\begin{array}{l}\text { Manner of } \\
\text { poisoning }\end{array}$ & $\begin{array}{l}\text { Total no. of } \\
\text { cases }\end{array}$ & Percentage \\
\hline Accidental & 89 & $32.7 \%$ \\
\hline Suididal & 178 & $65.4 \%$ \\
\hline Homicidal & 2 & $0.7 \%$ \\
\hline Don't know & 3 & $1.1 \%$ \\
\hline
\end{tabular}

Regarding the mode of transportation (Table 11), 66.5\% $(n=181)$ of cases chose to ride/drive their own vehicle to come to hospital, $16.9 \%(46)$ and $16.2 \%(n=44)$ chose auto/taxi and ambulance respectively. Coming to the immediate outcome of the patient (Table 12), 82.4\% $(n=224)$ of the cases survived and were admitted to the hospital, $16.9 \%(n=46)$ cases survived and had been referred to the higher centers and only $0.7 \%(n=2)$ cases died and were subjected to medico-legal autopsy. 
Table 9: Alleged reason for poisoning among those who attempted suicide.

\begin{tabular}{|lll|}
\hline Reason & $\begin{array}{l}\text { Total no. of } \\
\text { cases }\end{array}$ & Percentage \\
\hline Depression & 1 & $0.6 \%$ \\
\hline Education related & 2 & $1.1 \%$ \\
\hline Financial crisis & 1 & $0.6 \%$ \\
\hline Dowry & 1 & $0.6 \%$ \\
\hline Family problem & 9 & $5.1 \%$ \\
\hline Dint tell & 164 & $92.1 \%$ \\
\hline $\begin{array}{l}\text { Total number of } \\
\text { suicidal poisoning }\end{array}$ & 178 & $100 \%$ \\
\hline
\end{tabular}

Table 10: Person accompanying along with the patient.

\begin{tabular}{|lll|}
\hline $\begin{array}{l}\text { Person } \\
\text { accompanying }\end{array}$ & $\begin{array}{l}\text { Total no. of } \\
\text { cases }\end{array}$ & percentage \\
\hline Self & 36 & $13.2 \%$ \\
\hline Parents & 45 & $16.5 \%$ \\
\hline Siblings & 40 & $14.7 \%$ \\
\hline Friends & 12 & $4.4 \%$ \\
\hline Relatives & 4 & $1.5 \%$ \\
\hline Neighbour & 4 & $1.5 \%$ \\
\hline Spouse & 19 & $7.0 \%$ \\
\hline Guardian & 2 & $0.7 \%$ \\
\hline Others & 110 & $40.4 \%$ \\
\hline
\end{tabular}

Table 11: Mode of transportation.

\begin{tabular}{|lll|}
\hline $\begin{array}{l}\text { Mode of } \\
\text { transportation }\end{array}$ & $\begin{array}{l}\text { Total no. of } \\
\text { cases }\end{array}$ & \begin{tabular}{l} 
Percentage \\
\hline Own vehicle
\end{tabular} \\
\hline Ambulance & 181 & $66.5 \%$ \\
\hline Auto/taxi & 44 & $16.2 \%$ \\
\hline Others & 46 & $16.9 \%$ \\
\hline
\end{tabular}

Table 12: Immediate outcome of poisoning.

\begin{tabular}{|lll|}
\hline Outcome & $\begin{array}{l}\text { Total no. of } \\
\text { cases }\end{array}$ & Percentage \\
\hline Survived and referred & 46 & $16.9 \%$ \\
\hline Survived and admitted & 224 & $82.4 \%$ \\
\hline $\begin{array}{l}\text { Dead and subjected to } \\
\text { autopsy }\end{array}$ & 2 & $0.7 \%$ \\
\hline
\end{tabular}

\section{DISCUSSION}

The extent of poisoning morbidity and mortality in a society reflects the socio-economic as well as the mental state of the society. In India and other developing nations, especially among rural regions, pesticide poisoning from occupational, accidental and intentional exposure is a major problem. In present study, there was a higher incidence of poisoning in males $(63.2 \%)$ as compared to females $(36.8 \%)$ and most of the poisonings were in the age group of $19-30$ years $(48.1 \%)$, followed by $26.8 \%$ in
31-50 year age group. These results are similar to studies done by Rao S. et al ( $57 \%$ and $43 \%, 2 / 3$ rd patients <30 years), Purnanand $\mathrm{N}$ et al $(79.5 \%$ and $43 \%, 41.02 \%$ in the age group of 41-50 years), Sharma BR et al (63\% and $27 \%$, majority cases in 21-25 years age group and Ramesha KN et al (75.4\% and $24.6 \%$, majority in $20-29$ years age group $(31.2 \%)$, followed by $12-19$ year age group). ${ }^{10-13}$ This high incidence in this age group among males are attributed to point that males are more exposed to stress and have the responsibility to take care of the family and other financial matters.

Since Chamarajanagar district hospital is the only major hospital located in the surrounding areas, much of the rural population comes here for treatment. Hence, $75.7 \%$ of cases studied are from rural background. Maximum numbers of cases were reported during the month of March closely followed by June and during 12:01 to 18:00 hours. More than 2/3rd of the cases were reported within the golden hour of treatment i.e., within 6 hours of the incident. Similar findings were noted in studies done by Jesslin et al which states that more number of cases was noted during summer season and major number of cases were reported during day times. ${ }^{14}$ However, Pokhrey et al states that more cases were reported during rainy season and during night times. ${ }^{15}$ Water and electricity scarcity among rural areas during summer leads to crop failure and financial loses which indirectly increases the incidence of suicide. And also grains are preserved during summer season for which pesticides are procured, that increases the availability of poison and indirectly it leads to rise in the incidence during summer.

Irritant poisons accounts to the highest incidence (68\%) among poisoning in present study. Pesticides, organophosphorus compound in particular form the major type of poisons among Irritants followed by snake bite, rat poison and honey bee bite (sting). Similar results were noted in South Indian studies done by Ramesha et al, Jesslin et al, Jaiprakash et al and Vinay et al. ${ }^{13,14,16,17}$ However, in contrast, studies done in North India by Bajaj et al and Singh et al shows that the incidence of aluminium phosphide was found to be high. ${ }^{18,19}$ As agriculture is the main occupation of the people in and around Chamarajanagar district and organophosphorus compounds were commonly used pesticide in these localities, the most commonly used agent for poisoning was organophosphorus compound. Though majority of the patients have not revealed the exact reason for committing suicide by poison, it appears that family problems, unemployment, crop failure, financial crisis were the prime reasons for committing such an act. Similar theories have also been put up by other studies (Virendar et al) which state that factors like dowry, cruelty by the in-laws, family quarrels, maladjustment in married life and dependence of women on husband are responsible for the higher incidence of poisoning among house wives and failure in the exams or inability to cope up the high expectation from parents and teachers has increased the incidence of poisoning among students. ${ }^{19}$ 


\section{CONCLUSION}

This study highlights the profile of poisoning cases admitted to the Chamarajanagar district which clearly indicates the high risk population involved and the common poisons encountered in these region. Proper steps with multi-centric approach have to be taken by appropriate authority in future to reduce the incidence of poisoning and effective strategic preventive measures should be taken to prevent such acts.

\section{ACKNOWLEDGEMENTS}

Authors would like to thank all the faculty of casualty and medical records department.

Funding: No funding sources

Conflict of interest: None declared

Ethical approval: The study was approved by the Institutional Ethics Committee

\section{REFERENCES}

1. Thomas WF, John HD, Willium RH. Stedman's medical dictionary. $28^{\text {th }}$ edition. Lippincott William and Wilkins, New York; 2007:2004.

2. Thomas M, Anandan S, Kuruvilla PJ, Singh PR, David S. Profile of hospital admissions following acute poisoning experiences from a major teaching hospital in South India. Adverse drug React Toxicol. Rev. 2000;19:313-7.

3. Mohanty MK, Kumar V, Bastia BK, Arun M. An analysis of poisoning deaths in Manipal, India. Vet Hum Toxicol. 2004;46:208-9.

4. Lall SB, Peshin SS, Seth SD. Acute poisoning a ten years retrospective study. Ann Natl Acad Med Sci. 1994;30:35-44.

5. Dalbir S. Aluminium phosphide fatalities: A 24 years' experience. J Indian Acad Forensic Med. 2007;29(1):12-5.

6. World Health Organization. Guidelines for poison control Bulletin. Geneva: World Health Organisation. 1999.

7. Devi S. Toxicology, general consideration. In: Reddy NKS. Essentials of Forensic Medicine and Toxicology. $33^{\text {rd }}$ edition: Hyderabad; Jay Pee Brothers; 2014:446-65.
8. Gargi J, Tejpal HR. A retrospective autopsy study of poisoning in the northern region of Punjab. J Punjab Acad Forensic Med Toxico. 2008;2:17-20.

9. Aaron R, Joseph A, Abraham S, Muliyil J, George $\mathrm{K}$, Prasad J et al. Suicides in young people in rural southern India. Lancet. 2004;363:1117-8.

10. Rao CHS, Venkateswarlu V, Surender T, Eddleston M, Buckley NA. Pesticide poisoning in South India opportunities for prevention and improved medical management. Trop Med Int Health. 2005;10(6):581 8.

11. Purnanand NS, Huddar MG. Pesticide poisoning among agriculturists of Dharwad district: a study. Recent Research Sci Tech. 2010;2(4):109-11.

12. Sharma BR. Toxicological emergencies and their management at different health care levels in Northern India an overview. J Pharmaco Toxico. 2006;1(1):69-81.

13. Ramesha KN, Rao KBH, Kumar GS. Pattern and outcome of acute poisoning cases in a tertiary care hospital in Karnataka, India. Indian J Crit Care Med. 2009;13(3):152-5.

14. Jesslin J, Adepu R, Churi S. Assessment of prevalence and mortality incidence due to poisoning in a south Indian tertiary care teaching hospital. Ind J Pharm Sci. 2010;72(5):587-91.

15. Pokhrel D, Sirjanapant, Pradhan A, Mansoor. A comparative retrospective study of poisoning cases in central, zonal and district hospitals. Kathmandu Uni J Sci Eng Tech. 2008;1(5):40-8.

16. Jaiprakash H, Sarala N, Venkatarathnamma PN, Kumar TN. Analysis of different types of poisoning in a tertiary care hospital in rural south India. Food Chem Toxicol. 2011;49(1):248-50.

17. Vinay BS, Gurudatta S, Pawar, Inamadaa PI. Profile of poisoning cases in district and medical college hospitals of north Karnataka. Indian J Forensic Med Toxico. 2008;2(2):7-12.

18. Bajaj R, Wasir H S. Epidemic of aluminium phosphide poisoning in northern India. Lancet. 1988; 11:820.

19. Singh VP, Sharma BR, Harish D, Vij K. A ten year study of poisoning cases in a tertiary care hospital. Indian J Forensic Med Toxico. 2004;2(1).

Cite this article as: Srinivasa K, Yadukul S, Madyastha M. Study of profile of poisoning cases reported to district hospital, Chamarajanagar, Karnataka, India. Int J Basic Clin Pharmacol 2016;5:1215-9. 